\title{
UNDERSTANDING METHODOLOGY OF FIQH SOSIAL
}

\author{
Umdatul Baroroh \\ Institut Pesantren Mathali'ul Falah, Pati, Indonesia \\ Email: umdah@ipmafa.ac.id
}

\begin{abstract}
This article aims at developing the methodology of fiqh sosial by exploring the concept of fiqh sosial that Kiai Sahal thought. It is very important to do this research. The research used the qualitative method. I conducted this research through a literature study by exploring Kiai Sahal's writings as a primary source and analyzing them by collaborating with observations on social movements that he had carried out during his life. The results of the analysis and observations become the main ingredients in building a fiqh sosial methodology. Next is combining the data with fiqh methodology and social knowledge, sciences, technology, and other modern sciences. That is important because fiqh sosial must be able to produce the Islamic law that can able to realize the benefit of mankind and contextual wherever and whenever it be. Since the ideas of fiqh sosial have been published by Kiai Sahal, a lot of researchers and academics have written the theme. But of all the writings that already exist, almost no one has written about its methodology. If found, it is still very shallow and inadequate.
\end{abstract}

Keywords: Fiqh Sosial; Methodology; Kiai Sahal Mahfudh; Mashlahah

\section{Introduction}

"Fiqh Sosial" that was recognized by Kiai Sahal Mahfudh since the eighties era has been interesting wide muslim community. Therefore, it was not surprised if since the nineties era until now, many research and academic writings on fiqh sosial perspective were spread around the university and Islamic boarding (Pesantren). At that time, as a new fiqh model, fiqh sosial was been a new hope for pregressive fiqh in the future. Fiqh sosial has been chosen to be a problem solver for stagnation and muslim problematic correctly.

Among those who have researched on fiqh sosial is Sumanto Al Qurtubi. He wrote a book on title "K.H. MA. Sahal Mahfudh Era Baru Fiqh Indonesia", (Qurtubi, 1999). Another research about fiqh sosial is (Zubaidi, 2007) about empowerment, about civilization (Asmani, 2014) also most recently there are some young people have writing about fiqh sosial, for example "Aplikasi Fiqh Sosial KH. M.A. Sahal Mahfudh Terhadap Batas Usia Perkawinan dalam Pasal 7 ayat 1 Undang-Undang Perkawinan" (Hakim, 2019). 
Unfortunetely, most of reseachs and academic publications have not explained the methodology of fiqh sosial as a method of thinking. Most of reseaches and writer merely interpret the ideas of Kiai Sahal's thinking on fiqh sosial, especially from his book, Nuansa Fiqh Sosial, published by LKiS on '90s. Among the writers who have written about the methodology of fiqh sosial is (Aulia, 2017). Kiai Sahal, himself, has not explained the methodology of fiqh sosial in his work. Even in his master piece, Thariqah al-Husul ala Ghayah al-Wushul. Therefore, since 2012 I and all of the researchers at Fiqh Sosial Institute (now PUSAT FISI) have researched to systematize the ideas of fiqh sosial by developing fiqh sosial methodology in the body of knowledge.

We conducted this research by tracing the writings of Kiai Sahal, both in Indonesian and Arabic. Beside of written data, we also observed social movements that had been carried out by Kiai Sahal during his life. Because he has applied this thought of fiqh sosial in real social movements through community assistance, the establishment of economic, educational, and health institutions to empower the community. Then, we effort to collaborate primary data with the social sciences. That was an effort to realize the legal objectives that are always contextual in their time.

\section{The Meaning of "Fiqh Sosial"}

In the Arabic term, fiqh is derived from the root word: faqiha-yafqahu, fiqhan. (Al-Munjid, Tanpa Tahun). It means understanding or deep understanding. In the Islamic jurisprudence, fiqh means the knowledge of the shari'ah rulings which are related to actions from its detailed sources.

العلم بالأحكام الثر عية العملية المكتسب من أدلتها التفصيلية (Zahrah, Tanpa Tahun) .

While the word 'social' is having to do with human being living together as a group in a situation in which they're dealing with one another affect their common welfare. So, the fiqh sosial means the knowledge of the shari'ah rulings which are related to actions from its detailed sources for the welfare or benefit of the people (Baroroh \& Janah, Fiqh Sosial Masa Fiqh Indonesia, 2016).

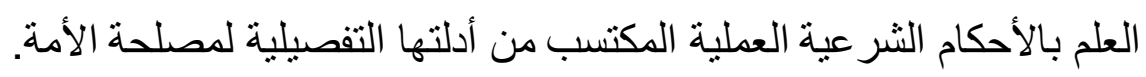


From this definition, we can know that fiqh was the result of texts understanding or interpretation. The law (hukm) itself in the Usul Fiqh term is The Word of God related to the actions of mukalaf or someone burdened with the law. There are two kinds of law in the shari'ahh term; taklifi and wadh'i. Taklifi is the law that burden human being either doing or avoiding it. Wadhi'i is a law that explains the origin of law like causes (sabab), conditions (syarat), legalities (sah) or otherwise (Al-Asyqar, $1417 \mathrm{H}$ ).

The effort of legal excavation is usually done by a mujtahid (people who excavate the legal or law from some texts), and the law as the result of his excavation called fiqh. In the fiqh studies, there are many mujtahids who do this project, like imam Syafi'i, Hanafi, Maliki, or Hambali. So, they can have a different opinion on signing legal problems. The differences happened from different background, perspective, social context, etc. that have born the various madzhab on fiqh studies. The various madzhab on fiqh was motivated by varieties of background. (Sirry, 1995). Some of them motivated by ideology (so we get syi'i or sunni fiqh), or geography (differences of places), so we can find school (madzhab) of Bashrah, Kufah, Bagdad, Mesir, etc. In another place we also find the madzhab motivated by the person become figure or leader that followed. Therefore we have seen the school of Hanafi, Maliki, Syafi'i, or Hambali. (Sirry, 1995) Apart from them, there were schools of thought (madzahib) in fiqh study. Even in the history of Islamic law, there were nineteen schools of fiqh thought (madzhab) ever live in muslim community. But, most of them couldn't exist to be authoritative schools in the history of fiqh, except four schools (madzhabs) above and some of the other schools in Syi'ah community (Baroroh \& Janah, Fiqh Sosial Masa Fiqh Indonesia, 2016).

The existence of schools (madzhab) in fiqh has shown to us that different ideas and thoughts were a necessity. Because of that, we must put fiqh as a legal result produced by mujtahids or ulamas depend on their perspective and social background. In this case, we can learn from Imam Malik. When Imam Malik was asked for permission that his fatwas would become state schools (madzhab), he suddenly refused to allow them because he was afraid that his opinions would be truthful. He also added that the Prophet himself let his companions fight 
on furu'iyah matters (Al-Asyqar, 1417 H). Imam Shafi'i, when asked about the truth of his legal opinion, answered that his opinion was right but there was a possibility of being wrong. While the opinion of others according to him is wrong, but there is still a possibility of being right. The answers given by Imam Malik and Shafi'i implies an ethical understanding of fiqh for the Islamic community. Both of them seemed to confirm that the truth of fiqh was very relative. That truth is not binding on anyone, other than mujtahid and those who believe in it.

\section{The Main Principles of fiqh sosial}

After understanding the definition of fiqh sosial, we need to understand the main principles of fiqh sosial. But before that, we need to recognize Kiai Sahal's perspective on humanity. This is very important to help us to understand the basic logic in fiqh sosial. Because this perspective becomes the main foothold of the Kiai Sahal in building and developing fiqh sosial going forward.

Kiai Sahal starts his explanation of human essence (Mahfudh, 2004). As confirmed in the Koran, that man was created by God to carry out the task as the caliph of God on earth (al-An'am:165). The Khalifah means god substitute. As caliph of god on earth, humans are obliged to carry out these two functions of the caliph, namely ibadatullah (worshiping Allah) and imarah al-ardh (conserving life on earth). So, as the caliph of God, man is obliged to worship Allah as a consequence of his status as a creature that must obey the Creator. They are also obliged to conserve life on earth (imarah al-ardh). The two functions above must be carried out simultaneously and balanced. It cannot be biased or neglected in either case (Baroroh \& Janah, Fiqh Sosial Masa Fiqh Indonesia, 2016).

To facilitate humans in carrying out their duties, Allah provided them with the main guidelines, namely the Holy Koran and the Hadith. As a human guideline in carrying out the khilafah, of course, the Koran and the Hadith must contain guidance on worship as well as guidance on how to prosper the earth. Therefore, if we look at the content of the Koran and the Hadith always contains matters relating to worship as well as matters relating to the prosperity of the earth and the universe. After the Prophet's death, the Koran and Hadith have been stopped. We can no longer wait for the coming of the Koran and Hadith when facing problems in life. Meanwhile, the problems faced by humans do not stop. 
This encourages the scholars to develop guidelines that already exist in the Koran and Hadith so that it can always be used as a foothold for humans in carrying out the duties of the Khilafah. This development is a factor that causes the existence of fiqh. Then fiqh should be able to be a guideline for humans to carry out their duties of khilafah. Therefore it must contain instructions about the two functions above, ibadatullah (worship to God) and imarah al-ardh (conserve the earth). Balance in carrying out the task of human khilafah is intended to realize the benefit in human life. If humans can carry out these tasks, then they will be able to achieve the highest goal of their life; happy in the world and the hereafter ( $s a^{\prime} a d a h$ fi al-darain).

The following is a description of the structure of the figh sosial relationship with the purpose of humanity:
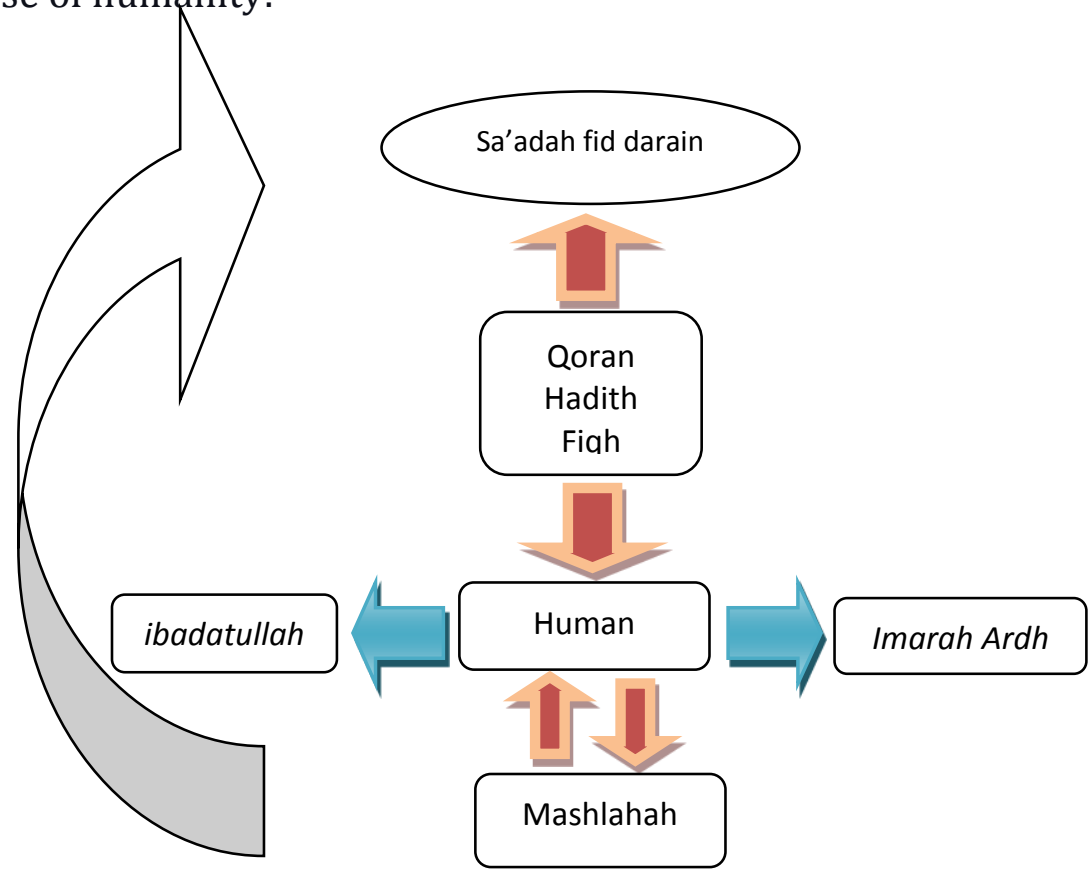

But, in Islamic history, the fiqh was more focused on matters of worship and less attention to matters of prosperity on earth. We can see that from the themes in fiqh. If we observe from the books of fiqh we can find the attention of fiqh always dwelling on worship (ubudiyah) themes, such as prayer, zakat, fasting, or pilgrimage. Besides the theme of ubudiyah, fiqh also talks about the theme of mu'amalah (economics), jinayah (criminals), and siyasah (politics). But if we examine it deeper, in matters relating to mu'amalah it is always directed to ubudiyah. The concern of fiqh which is more directed to ubudiyah or 
ibadatullah than to imarah al-ardh, shows the failure of fiqh in balancing the function of khilafah. As a result, many Muslims also neglect the matter of imarah al-ardh and focus more on the ubudiyah matter. This imbalance becomes an obstacle to the realization of the benefit of humans (mashlahah ammah) and the achievement of other goals (Baroroh \& Janah, Fiqh Sosial Masa Fiqh Indonesia, 2016)

From the basic meaning of humanity above, then we can understand the basic principles of fiqh sosial as foothold in developing fiqh sosial. There are five basic principles of fiqh sosial (Mahfudh S. , 2004): (1) Interpretation of fiqh texts contextually; (2) Changes from the textual approach (qauli) to methodologically approach (manhaji); (3) Fundamental verification which are the main teachings or text (ushul) and which are branches (furu'); (4) Presenting fiqh as social ethics, not as state regulation; (5) Introduction to philosophical values, especially in cultural and social issues.

From the five principles above, we have been able to find the basic foundation of how fiqh sosial works in solving people's problems. We can take the basic outline as follows:

1. An absolute necessity for contextualizing the law. Because a legal product is a result of thinking that is limited in space and time. Therefore bringing a law to a different context without the same process of adjustment as a rape of the law.

2. Recognition of classical text (turats) as the first step in developing of Islamic law. That we can see from the third principle that requires verification of the principal teachings and the branch. This shows that the development of fiqh must remain grounded in the basic foundation of Islamic shari'ah teachings. The main teachings have at least been summarized in the five basic principles of shari'ah (maqashid shari'ah shari'ah).

3. The necessity for a renewal of the legal formulation methodology to be a legal reproduction tool. This is a key answer to the demands on the contextualization of fiqh law itself. Because the legal reproduction demands are not possible without the availability of production tools. 
This renewal is not going to destroy the old building but rather to renovate and restore the existing building of methodology (Baroroh \& Janah, Fiqh Sosial Masa Fiqh Indonesia, 2016).

\section{The Methodology of Fiqh Sosial}

After we recognize the meaning of fiqh sosial, then we need to know the methodology of it. The methodology is needed as a tool to interpret the law in solving people's problems. fiqh sosial needs to have its own set of methodologies that can be the lens in producing law for the problems of the people. Therefore the methodology is very urgent. The methodology is needed as a testing tool for propositions or procedures used to measure the truth of knowledge. It means that knowledge is valid if it has the right and valid procedure. In fiqh studies, methodology means the way that leads the jurist (mujtahid) to the legal outcome. With the correct methodology, the results of the legal formulation can be considered valid.

There is a clear statement from Kiai Sahal in 'Nuansa fiqh sosial' (written by Kiai Sahal) when Kiai Sahal explains the basic foundations of fiqh sosial method:

"Secara qauli pengembangan fiqh bisa diwujudkan dengan melakukan kontekstualisasi kitab kuning atau melalui pengembangan contoh-contoh aplikasi kaidah-kaidah uhsul fiqh maupun qawai'id fiqhiyah. Sedangkan secara manhaji melalui pengembangan teori masalik al-illat agar fiqh yang dihasilkan sesuai dengan mashlahah al-'ammah (Mahfudh S. , 2004).

(In qauli approach, the development of fiqh can be realized by contextualizing the yellow book (kitab kuning/turats) or through the development of examples of the application of the uhsul fiqh rules or qawai'id fiqhiyah. While manhaji approach can be realized through the development of the theory of masalik al-illat to the fiqh produced with the mashlahah al-'ammah [people benefit] appropriate)

The statement above explains that one important point in the basic principle of figh sosial is moving from the qauli approach to the manhaji approach. Furthermore, in that statement, Kiai Sahal has mentioned explicitly how to realize both qauli and manhaji meaning.

From this explanation, we can understand that both qauli and manhaji approach must be used in legal extract (istinbath). Because the development of fiqh sosial exemplified by Kiai Sahal always builds on the principle of 'al-muhafadzah ala al-qadim al-shalih wa al-akhdzu bi al-jadid al-ashlah' (keep good old traditions and take new traditions better). This principle teaches us to appreciate turats as 
the heritage of predecessors (al-salaf al-shalih), and not to deny the renewal that is the demand of the times. Both must be placed in a balanced way to maintain the elasticity of fiqh and its suitability at all times.

\section{Madzhab Qauli in the Fiqh Sosial}

The development of fiqh sosial has been carried out through two stages. The first stage is using the qauli approach. That is, when we want to answer masail waqi'iyah (daily problems faced by Muslims), the first thing we have to do is use the qauli approach or textual approach. The qauli approach in fiqh sosial can be done in two ways. The first is through searching the text from the Koran, Hadith, or opinions of the scholars who have been in the yellow book (kitab kuning/turats). So far, the first model of qauli approach has always been prioritized in finding the law, particularly among Sunni scholars, especially NU. In the bahtsul masail (discussing the problems) tradition which was carried out by NU ulemas when answering the masail waqi'iyah (problems,) the ulema has always searched of fiqh texts from the yellow books (kitab kuning/turats) that were recognized (mu'tabar.) The debate that occurs is usually to maintain one text over another text that is intended to serve as a legal basis.

Second, the qauli approach can be applied through the development of qawaid fiqhiyah and ushuliyah. This is as confirmed by Kiai Sahal in the quote above. But the second meaning is less popular among NU ulemas. The ulemas are very careful to establish the law using qawaid fiqhiyah or ushuliyah. They worry that it could cause carelessness in setting the law. For example in the method (qaedah) of "Dar 'al-mafasid muqaddamun ala jalb al-mashalih" (Refuse damage must be prioritized rather than realizing benefit). Ulema are very careful in interpreting mafsadah and mashlahah in real life. Al-Suyuthi exemplifies the ability to lie when it can prevent someone from slander. Such examples continue to be internalized to the next students. The teacher or Kiai is reluctant to develop applicative examples in this life, because of his caution (Al-Suyuti, Tanpa Tahun).

Qawaid fiqhiyah is very appropriate to be one alternative that can be used to answer new problems faced by Muslim society today. The qaida above, for example, can be used as a foothold in determining the legal case of polygamy. Polygamy which is considered to have mashlahah value because it was allowed by 
a clear text can be prohibited if in reality, it causes mafsadah or damage in domestic life. It was the law decision made by Abduh in Mesir (Sam'un, 2012). They were the two meanings of qauli that have been explained by Kiai Sahal as qauli approach in fiqh sosial. If the qauli cannot be used, we must continue to the next step, namely the manhaji.

\section{Madzhab Manhaji in Fiqh Sosial}

Manhaji school is the second step when the school of qauli can no longer answer the problem. Kiai Sahal explained that the Manhaji school of thought can be used through the development of masalik al-illah. He said: "Sedangkan secara manhaji melalui pengembangan teori masalik al-illat agar fiqh yang dihasilkan sesuai dengan maslahat al-'ammah” (Mahfudh S. , 2004). (The manhaji approach can be developed through masalik al-illat theory, so that the fiqh produced in accordance with the common benefits (mashlahah al-'ammah").

The explanation, according to me, implies several important things. Firstly, there is an absolute recognition of ijtihad as an effort to develop masalik al-illat. Secondly, it is important to combine the necessity of ijtihad with the obligation to realize the mashlahah. Meanwhile, the way offered by Kiai Sahal at that time was through the development of masalik al-illat (Baroroh \& Janah, Fiqh Sosial Masa Fiqh Indonesia, 2016).

This means Kiai Sahal wants to applie qiyas more as a method to answer the problem in ijtihad (Baroroh, Menelusuri Genealogi Metode Pengembangan Fiqh Kiai Sahal, 2014) . Qiyas is analogous to the new case law with the old case law contained in the Koran or Hadith because of the similarity of illat (Al-Asyqar, 1417 H). There are four pillars in the qiyas method; ashl (nash), ashl's law, far '(new case), and illat. Thus illat becomes one of the important pillars needed to find a law of far' (branch) or new case. Without illat, qiyas is not possible to applied. But the use of masalik al-illah as the implementation of the Manhaji school of thought by Kiai Sahal, according to me, does not mean to limit.

This is very important for us to underline. Because the development of masalik al-illat is the way (wasilah) to achieve the goal (ghayah). While the goal itself is to realize the maslahah ammah. Mashlahah itself is the main goal of shari'ah application (maqashid shari'ah). The objectives of the shari'ah according to 
Al-Ghazali are five, namely protecting religion (hifdz al-din), soul (hifdz al-nafs), reason (hifdz al-aql), descendants (hifdz al-nasl), and property (hifdz al-mal). The five goals above are classified into three levels, dharuriyyat (primary), hajjiyyat (secondary), tahsiniyyat (tertiary) (Al-Ghazali, Al-Mustashfa, 1993).

Although ulemas agree that mashlahah is the goal of shari'ah (maqashid shari'ah shari'ah), but they disagree when making it as one source of legal determination. One scholar who avoids using mashlahah as a source of law is Imam Shafi'i. He only recognizes four sources of law in Islam, namely the Koran, Hadith, ijma 'and qiyas. Qiyas in Syafi'i school is the only field of ijtihad development. All problems that are not found in the Koranic text, Hadith, or the results of ijma 'ulemas will be resolved through qiyas (Baroroh, Menelusuri Genealogi Metode Pengembangan Fiqh Kiai Sahal, 2014).

Therefore Shafi'iyah scholars try to expand the reach of the qiyas by developing masalik al-illah. Without qiyas, ijtihad would no longer find its field of work. In this context, mashlahah is read as the wisdom (hikmah) of establishing a law, not an approach to establishing a law. They argued that it was very difficult to identify mashlahah objectively. While the law must apply constantly and clearly.

Masalik al-illah is a way to find reasons (illat) used in determining the law (Salqini: 1996). Illat can be found through several stages. First, it is through texts of the Koran and Hadith. Second, through ijma 'ulema. Third, through ijtihad by seeing its suitability (al-munasabah) or through verification and testing (al-sabr wa al-taqsim). In oter version, ijma' is the first way in masalik al-illah (Mahfudh M. S., 2012). Thus the ijtihad field will be focused on the area of the development of masalik al-illah (Al-Asyqar, $1417 \mathrm{H}$ ).

When Kiai Sahal explained the manhaji through the development of masalik al-illah, he was demonstrating his commitment to holding the Shafi'i school (madzhab). So, is the development of masalik al-illah the only method to apply manhaji? Although we explicitly get an answer like that, according to me, it is too fast to get a conclusion. From the beginning, the challenge and the duty of fiqh sosial was to answer the problems of people throughout the ages. Therefore the methodology must be designed in deeper and detail design. I think the references used also must be broader in looking at the figure of Kiai Sahal. Not only what is 
written and spoken, but also must be collaborated in everything has been done in real action by Kiai Sahal and understanding the context in which it exists.

Fiqh Sosial which we will make as a model of Indonesian fiqh, is impossible to be supported by qiyas only. Every time we can see many problems have developed more and fast that is not found in the legal text. Or they could be found in the legal text, but its application is no longer possible to use or not contextual. Then we need another way to answer the problems. Therefore, qiyas was not enough to be only one as an approach within ijtihad. At the second level of the Manhaji approach, we can borrow the methodology used by ulemas of the other syafi'ian schools (madzhab). For example, we can borrow the istihsan approach from Hanafi or mashlahah mursalah from Maliki. Both approaches are not used in the Shafi'i school of thought. But the necessity of contextualization as the basic principles of fiqh sosial, requires to open all of the ijtihad method used by ulemas, not only syafi'i but also another (Baroroh, Aplikasi Madzhab Manhaji Ikhtiar Menggagas Metodologi Ijtihad Fiqh Sosial, 2015).

Besides requiring openness to borrow other methods of ijtihad madzhab, fiqh sosial must also consider the discovery of scientists that are growing rapidly today. Therefore, the third level of the Manhaji approach is an openness to accept all of the opinions across scientific fields, such as social knowledge, sciences, and technology. At this level, fiqh also needs to consider local wisdom so that it can be well received by the community (Kasdi, 2019). In ushul fiqh we know 'urf as one that can be considered in law. In qawaid fiqhiyah there is a qaidah: "al-adah muhakkamah" (customs can be reference law) (Al-Suyuti, Tanpa Tahun). This has become one of the keywords that can not be avoided. Today fiqh can no longer be left exclusively by closing itself off from other sciences. Fiqh whose object is related to all human practices really needs tools to analyze those practices more sharply. In matters of health, for example, advances in medical science and technology must be utilized by mujtahids in analyzing problems that arise. Kiai Sahal himself has done and advocated this in approaching various problems.

Unfortunately, Muslims still face the dichotomy of science, among religion and another science. Issues relating to religion are often considered religious monopolies. The field of not religious science has no right to interfere in giving 
consideration. On the other hand, general science also often does not care about the science of religion. Because they feel not working on those fields. As a result of this dualism, Muslims are often trapped in the dichotomies of harmful problems. Even as a result of such scientific dichotomy, legal products are often the target of public mockery. Therefore, such a perspective must be stopped immediately.

Thus the formulation of fiqh sosial methodology in producing the law is twofold. First, is the qauli approach. The qauli approach is carried out through the contextualization of fiqh texts and the development of the qawaid ushuliyah and fiqhiyah. Second, is the Manhaji approach. The implementation of Manhaji approach is carried out through three stages, namely the development of masalik al-illah, openness to other ijtihad methods, and openness to the discovery of modern sciences like social knowledge, science, technology, or others as a material for determining legal determination, and concidering local wisdom.

The following illustrates the flow of fiqh sosial methodology more simply:

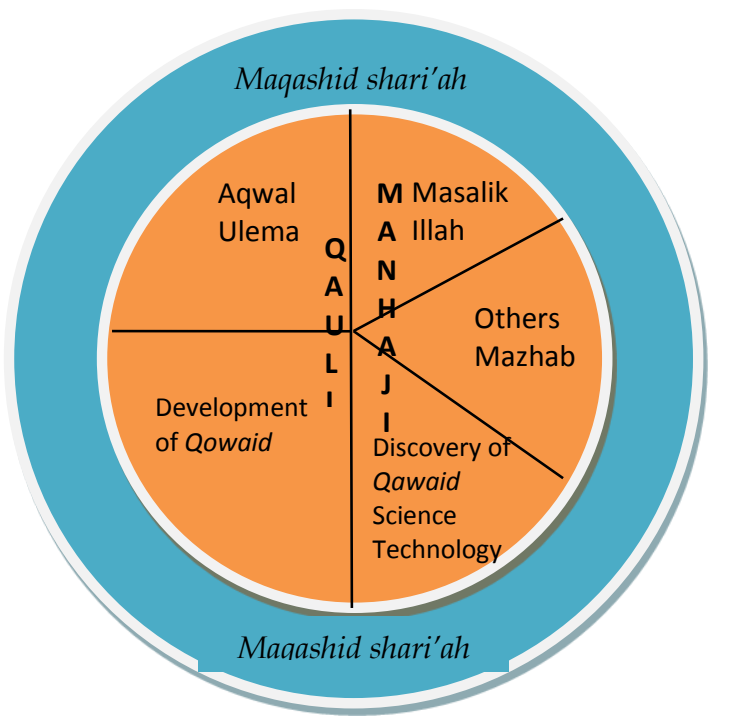

\section{Maqashid Shari'ah Position in Fiqh Sosial}

In the circle of methodology picture above, there is the maqashid shari'ah in the blue circle outside. Maqashid shari'ah in fiqh studies occupies an important position. Because it is the main aim of Islamic law. The same thing must also exist in fiqh sosial. Then where is the position of maqashid shari'ah in fiqh sosial methodology? Before answering the above questions, we should know the meaning of maqashid shari'ah. 
Etymologically maqashid shari'ah shari'ah consists of two words namely maqashid and shari'ah. Maqashid is a plural form of the word maqshad which is a derivation of the word qashada-yaqshidu (Al-Munjid, Tanpa Tahun). The meaning is the goal, fair or not overstepped, straight, middle or not excessive and deficient. While the word shari'ah comes from the word syara'a-yasyra'u, that in fiqh literature it is usually interpreted as a path to spring. (Al-Munjid, Tanpa Tahun). The term shari'ah itself is understood as all the provisions and laws contained in the Koran and Hadith (Zahrah, Tanpa Tahun). The maqashid shari'ah terminologically experiences a dynamic shift in meaning, from the simplest to the holistic meaning. That we can see from the history of the development of the maqashid shari'ah in the period of fiqh growth until now.

At the beginning of Islmic history, maqashid shari'ah was not widely explained in fiqh and ushul fiqh literature (Mawardi, 2012). Al-Raysuni said, among classical scholars before al-Syathibi has not found a clear and comprehensive definition of the meaning of maqashid shari'ah (al-Raysuni, 2005). Al-Ghazali only defines it as pulling benefit (jalb al-mashlahah) and rejecting damage (daf' al-mafsadah) (Al-Ghazali, Al-Mustashfa, 1993). Mashlahah itself means maintaining the five objectives of the Shari'ah, namely guarding religion, soul, reason, descent, and property (Al-Ghazali, Al-Mustashfa, 1993). Al-Amidi in al-Ihkam fi Usul al-Ahkam explained it very simply. "The aim of the Shari'ah is to bring benefit or refuse damage or a combination of the two" (al-Amidi, $1388 \mathrm{H}$ ).

The deficiency of attention of scholars in studying the maqashid shari'ah in the early era was allegedly due to the sharp friction of theological beliefs in Islamic groups. At that time, the maqashid shari'ah was highlighted. It began with a question of whether God should give benefit to every law handed down to humans. According to muktazilah who had the doctrine of al-shalah wa al-ashlah (God must do good and best for humans), then they obliged it (Nasution, 2008). But the Ash'ariah do not agree with them. Ash'ariah belief that God has the right to take any action as a manifestation of His nature. So it is not an obligation for God to give benefit to every law that is revealed. Meanwhile, Maturidiyah takes moderation between muktazilah and ash'ariah. According to them, God's actions do have a cause and purpose. But that is not an obligation for Him. While we know that fiqh 
is more developed among Sunnis whose creeds follow the Ash'ariah and Maturidiah. Of course, we can understand if the discourse about maqashid shari'ah is less popular during the growth of fiqh in the early era (Mawardi, 2012)

The figure who was credited with introducing a legal approach by using the maqashid shari'ah was al-Syathibi through his work, al-Muwafaqat. He states that taklif or burden in the shari'ah returns to the preservation of its goals towards beings. These objectives consist of three levels, namely dharuriyyat (primary), hajjiyyat (secondary), and tahsiniyyat (tertiary). He further added that Allah as the Shari' certainly has a purpose in every law he put down, namely for the benefit of humans in this world and the hereafter (Mawardi, 2012). Therefore he obliges every mujtahid who wants to do ijtihad to know the maqashid shari'ah, besides understanding the Koran and Hadith as its main source. He even put this knowledge of maqashid shari'ah in the first of the two requirements of ijtihad. Because he considers that knowledge of maqashid shari'ah is the main basis for understanding the law. That is as explained by Abu Zahrah in his usul fiqh:

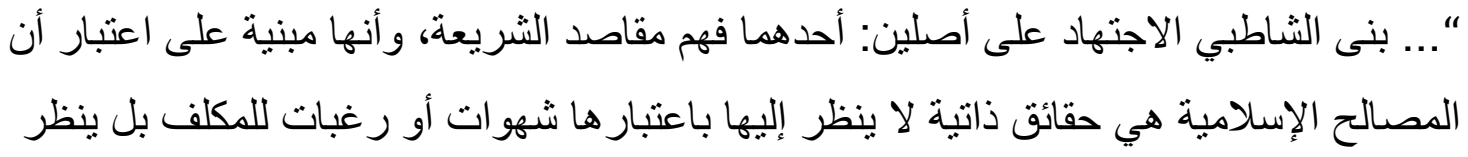
(Zahrah, Tanpa Tahun)." فيها إلى الأمر في ذاته من حيث كونه نافعا في ذاته أو ضار

"Al-Syathibi built ijtihad on two foundations. First, is understanding maqashid shari'ah. This is based on the assumption that benefit in Islam is an essence whose existence is not merely a mere consideration of pleasure or lust. But because of the essence of the law itself in terms of benefits or disadvantages."

Only in the hands of al-Syathiby, the study of maqashid shari'ah developed dynamically and applicatively. He not only explained the definition of maqashid shari'ah but also explained the concept of values up to the basic methods that must be passed in thinking using maqashid shari'ah. The great contribution of alSyathibi in the study of maqashid shari'ah according to Jasser Auda is three things. First, the shift in the meaning of maqashid shari'ah which is considered unclear and follows an unlimited interest (unrestricted interest) becomes the basic core in law (fundamental principle of law). Second, shifting the maqashid shari'ah as wisdom behind the law is the basis for legal regulation. Third, the shift in maqashid shari'ah 
which is considered dzanniyyah to be qath'iyyah (Auda, 2007). That is why alSyathibi boldly voiced the maqashid shari'ah as the main foundation of ijtihad, no longer as a means of justification.

After al-Syathibi, the study of maqashid shari'ah stopped until a young writer who returned to enliven it, Muhammad al-Thahir bin Asyur (d.1379/1973). He continued the great idea of al-Syathibi which he considered still failed in explaining the operationalism of the maqashid shari'ah in answering the problem of fiqh (masa'il fiqhiyah). Therefore in his book, Maqashid al-Shari'ah al-Islamiyah, he has ambitions to implement maqashid shari'ah in legal istinbath (Asyur, 2001). Besides that, according to Ahmad Imam Mawardi, Ibn Asyur also asserted that hurriyyah (freedom) based on musawah (egalitarianism), fithrah (purity), samahah (tolerance), al-haq (truth) as part of the maqashid shari'ah. According to him, that freedom gets legal protection from shari'ah, because it is a manifestation of the development of al-dharuriyyat al-khams (five objectives of shari'ah).

From the explanation above, I believe that the maqashid shari'ah should be the foundation and the direction of the provisions of law. Because the demand for the openness of thought in cross disciplines requires clear direction and footing. It was intended to avoid the law from the influence of interests and egocentrism.

Speaking maqashid shari'ah means talking about the benefit that must be realized in the determination of law. Although the scholars of fiqh (fuqaha) debate about its validity as a source of law, indirectly they also agree on the benefit. Their doubts and worries in using mashlahah are on limits and measurements that are difficult to explain. This is because of benefit as a value. Looking for a measure of value certainly cannot use physical measures. This is a new challenge for fiqh. Fiqh has always been understood formally and regardless of its contact with the area of value. It is often revealed that fiqh only deals with human physical actions. While inner actions are not the domain of fiqh, but Sufism. If today we still place fiqh at that limit, the dimension of fiqh is very low.

Revolutionary efforts towards the exoteric position of fiqh towards the esoteric have been carried out by al-Ghazali through his monumental work, Ihya 'Ulum al-Din. In that book, al-Ghazali tried to reconcile the position of fiqh and Sufism which had been far apart from being side by side. He criticized fiqh for 
ignoring Sufism or vice versa by saying: "Whoever practices fiqh without using Sufism has become wicked (fasiq). Whoever practices Sufism without fiqh then he has become zindiq [mysticism])" (Al-Ghazali, Ihya Ulum al-Din, 2003). What was done by al-Ghazali was a "mental revolution" towards the attitude of the fuqaha at that time.

Regarding values, the Prophet in one of the traditions stated "istafti qalbak", ask for fatwas from your own heart. This shows the basic conscience of humanity that has a standard of truth that can be accounted for. We also have the values inherited from the scholars in turats. We must use it and develop it in establishing the law. Because the values that have been passed down by turats are still very relevant for us to take today. About the benefits, for example, Ibn Qoyim al-Jauzi neatly provides a very simple benchmark below:

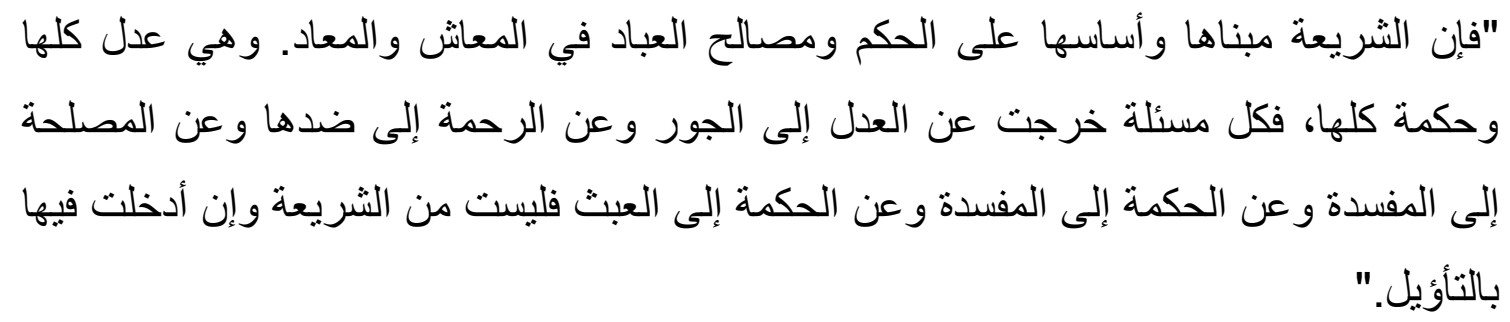

"Indeed the basis and foundation of shari'ah is human wisdom and benefit, both in world life and in the hereafter. Shari'ah is all about justice and wisdom. Therefore, every problem that goes from justice to despotism, from compassion to the opposite, from benefit to destruction, from wisdom to waste, then it is not included in the Shari'ah, even though it was entered using takwil ..." (al-Jauzi, 1977)

Wisdom in this kind of law must be a foothold in laying the foundations of fiqh sosial methodology. Excessive concern over legal engineering in the name of mashlahah can still be bridged by efforts to 'localize' mashlahah. That is, consideration of benefit as a legal basis is not always sufficient to follow the majority standard set by the ulema which is universal. It is also important to pay attention to the benefits needed by minority groups, such as women, the disabled, the poor, and others. So those who have not been able to reach the majority standard still get legal justice, because their interests are considered fairly. If this is not the case, then fiqh experts will have difficulty deciding the law.

Moreover, universal benefits are sometimes very difficult to find. Because of the limitations of human knowledge. How can we determine the universal benefit, 
in addition to the benefits set by the text? Our knowledge and experience are very limited by time and space. Likewise, the benefit that we need is also limited by space and time. Will these limitations limit us from reproducing the law? Of course, you can't. This is precisely what gives the extent of the mujtahid in making legal decisions. Legal differences that occur so far have also been influenced by differences in such contexts. But it was addressed by the mujtahid as a mercy for the people. In this context I prefer to choose to take the Maliki's manhaj which is more flexible in applying mashlahah, especially mashlahah mursalah. Of course, we agree that the benefit used must not be in direct conflict with the text. When we make mashlahah as a foothold in reproducing the law, more problems can be overcome by using the fiqh perspective. If so, it means that more and more of God's shari'ah is being realized on earth.

\section{Conclusion}

The research result on the methodology of fiqh sosial in this study is expected to be a bright light for the development of fiqh sosial in the future. This is very important. Because fiqh sosial is a new hope for future fiqh models. This fiqh not only presents a new name for fiqh but also presents a new approach, namely the manhaji approach. In this manhaji approach, fiqh sosial tries to combine several scientific dimensions, from religious knowledge to social knowledge and science, as well as local wisdom. The approach above is still wrapped in the perspective of the benefit (mashlahah) as a goal of the shari'ah that considers justice for minorities and majorities. So, fiqh can be a humanist legal solution, not merely normative. 


\section{Bibliography}

al-Amidi, S. A.-H. (1388 H). Al-Ihkam fi Ushul al-Ahkam. Beirut: Muassah alNur.

Al-Asyqar, M. S. (1417 H). Al-Wadhih fi Ushul al-Fiqh. Oman: Maktabah alDurar \& Dar al-Nafais.

Al-Ghazali. (1993). Al-Mustashfa. Beirut: Dar el-Kutub el-Ilmiyah.

Al-Ghazali. (2003). Ihya Ulum al-Din. Beirut: Dar al-Fikr al-Araby.

al-Jauzi, I. a.-Q. (1977). I'lam al-Muwaqqi'in an Rab al-Alamin. Beirut: Dar alFikr al-Araby.

Al-Munjid. (Tanpa Tahun). Beirut: Dar al-fikr.

al-Raysuni, A. (2005). Imam al-Syathibi's Theory of the Higher Objectives and Intensts of Islamic Law. London: Washington.

Al-Suyuti, J. (Tanpa Tahun). Al-Asybah Wa al-Nadzair. Surabaya: Syirkah Asiya.

Asmani, J. M. (2014). Fikih Sosial Kiai Sahal Sebagai Fikih Peradaban. AlAhkam, 31-46.

Asyur, M. T. (2001). Maqashid al-Shari'ah al-Islamiyah. Yordania: Dar alNafais.

Auda, J. (2007). Maqashid al-Shariah as Philosophy of Islamic Law a Systems Approach. London; Washington: The International Institute of Islamic Thought.

Aulia, A. (2017). Metodologi Fiqh Sosial M.A. Sahal Mahfudh. eL-Mashlahah.

Baroroh, U. e. (2014). Menelusuri Genealogi Metode Pengembangan Fiqh Kiai Sahal. In M. A. (Ed), Epistemologi Fiqh Sosial. Pati: Staimafa Press.

Baroroh, U. e. (2015). Aplikasi Madzhab Manhaji Ikhtiar Menggagas Metodologi Ijtihad Fiqh Sosial. In T. N. (ED), Metodologi FIqh Sosial dari Qouli Menuju Manhaji (p. 89). Pati: IPMAFA PRESS.

Baroroh, U. e., \& Janah, T. N. (2016). Fiqh Sosial Masa Fiqh Indonesia. Pati: IPMAFA PRESS.

Hakim, M. L. (2019). Aplikasi Fikih Sosial KH. M.A. Sahal Mahfudh terhadap Pembatasan Usia Nikah pada Pasal 7 ayat 1 Undang-Undang Perkawinan. Islamic Review, 207-234.

Kasdi, A. (2019). Reconstruction of Fiqh Nusantara Developing The Ijtihad Methodology in Formulating Fiqh from Indonesian Perspective. QIJIS, 239-266.

Mahfudh, M. S. (2012). Thariqah al-Husul ala Ghayah al-Wusul. Pati: Mabadi Sejahter.

Mahfudh, S. (2004). NUansa Fiqh Sosial. Yogyakarta: LKiS. 
Mawardi, A. I. (2012). Fiqh Minoritas Fiqh Aqalliyyat dan Evolusi Maqashid alSyari'ah dari Konsep ke Pendekatan. Yogyakarta: LKiS.

Nasution, H. (2008). Teologi Islam Aliran-Aliran Sejarah Analisa Perbandingan. Jakarta: Penerbit Universitas Indonesia.

Qurtubi, S. A. (1999). K.H. MA. Sahall Mahfudh Era Baru Fiqih Indonesia. Yogyakarta: Cermin.

Sam'un. (2012). Poligami Dalam Perspektif Muhammad 'Abduh. Al-Hukama, 101-116.

Sirry, M. A. (1995). Sejarah Fiqh Islam Sebuah Pengantar. Surabaya: Risalah Gusti.

Zahrah, A. (Tanpa Tahun). Ushul al-FIqh al-Islamy. Beirut: Dar el-Fikr elAraby.

Zubaidi. (2007). Pemberdayaan Masyarakat Berbasis Pesantren Kontribusi Fikih Sosial Sahal Mahfudh dalam Perubahan Nilai-Nilai Pesantren. Yogyakarta: Pustaka Pelajar. 
Understanding Methodology of Fiqh Sosial 